\title{
Investigation and Analysis of Humanistic Quality of College Physical Education Teachers
}

\author{
Xu Degang, Tian Zhenxiang* \\ Department of Physical Education, Zaozhuang University \\ Zaozhuang 277160, Shandong
}

\begin{abstract}
Starting from the investigation and analysis of the humanistic knowledge reserve of university physical education teachers, it is found that some university physical education teachers lack literature knowledge, historical knowledge, artistic knowledge and complete philosophy and law knowledge. Based on this, it is found that the ideals and beliefs of some university physical education teachers are not strong enough and their moral standards need to be improved. This paper puts forward some countermeasures to improve the humanistic quality of physical education teachers in colleges and universities.
\end{abstract}

Keywords-College physical education teachers; Humanistic quality; Human knowledge; Humanistic spirit

\section{INTRODUCTION}

Humanistic quality is mainly the humanistic knowledge a person hasas well astheinternalizedtemperament and accomplishment reflected from the knowledge. Humanistic quality is the ideological tendency of people to take human as the object, to take human as the center and to care for people in their words and deedsinfinitely. It is also the ultimate concern for the meaning of human existence. Humanistic quality is an important part of human spiritual civilization. The level of human humanistic quality is directly related to the development of the spiritual civilization in the whole society. Therefore, humanistic quality mainly includes three aspects, namely, humanistic knowledge, humanistic spirit and humanistic methods. Humanistic knowledge refers to literary knowledge such as literature, history, philosophyand art. Humanistic spirit refers to a stable inner trait formed by absorbing and internalizing humanistic knowledge. Humanistic method is the cognitive and practical method contained in humanistic thought[2].In the context of market economy, new requirements in talents cultivating have been put forward for colleges and universities, who are forced by the law of value and the law of supply\& demand to face the society and to train professionals neededby economic constructionaccording to the market.

However, China's economic system in the transition period, many things are not perfect enough now. Many colleges and universities only see the immediate market values, pursuing quick successes and instant benefits, leading to the myopia in education[3].Influenced by the factors mentioned above, there are some utilitarianteacherspaying attention to practical knowledge only. They show strong abilities in learning computer and foreign languagesbut show little interest in social science such as literature, history, philosophy, law or art

Therefore, it is particularly important to guide physical education teachers to gain new feelings and understanding of themselves, others and the environment by participating, observing and reflecting on physical education activities and situations on the basis of masteringand internalizing certain humanistic knowledge,in the process of which they canaccumulate rich humanistic knowledge. [4] Higher education belongs to terminal education. The quality of talent cultivation of the whole countryis directly influenced by the qualities of teachers, so it is of great significance to improve teachers' humanistic quality.

\section{RESEARCH OBJECT AND CONTENT}

\section{A. The object of study}

Physical education teachers in 20 colleges and universities from 5 provincesShandong, Jiangsu, Anhui, Hubei and Qinghai along with Tianjin Municipality.

\section{B. Research content}

Starting from the investigation and analysis of university physical education teachers' humanistic knowledge, this paper advances some basic countermeasures and suggestions on improving university physical education teachers' humanistic quality systematically and comprehensively.

\section{Research Methods}

1) Questionnaire survey method

400 questionnaires were sent out and 336 recovered,with the recovery rate being $84.0 \% .290$ questionnaires, including 208 done by males and 82 females, were valid.The effective rate was $86.3 \%$,

\section{2) Documentation method}

Through the China Journal Network ( CNKI ), we have consulted the database over the past 10 yearsand more than 100 articles and 20 books at home and abroad.

\section{3) Expert Interview method}

Visiting sports experts and professors in colleges and universities to collect information and materials related to the humanistic quality of sports teachers in colleges and universities. 
4) Mathematical statistics law

A database was establishedon the computer, and Excelwas used for statistics analyzing.

\section{RESULTS AND ANALYSIS}

A. Some college physical education teachers lack humanistic knowledge reserve for

1) Some college PE teachers lack literature knowledge.

TABLE I. SITUATION OF COLLEGE PHYSICAL EDUCATION TEACHERS MASTERING LITERATURE KNOWLEDGE

\begin{tabular}{|c|c|c|c|}
\hline & Questions & $\begin{array}{l}\text { Number of } \\
\text { correct entries }\end{array}$ & Correct ratio \\
\hline 1 & The Romance of the Three Kingdoms shows the historical life of...... & $\begin{array}{l}141 \\
141\end{array}$ & $\begin{array}{l}48.6 \% \\
48.6 \%\end{array}$ \\
\hline 2 & The author of " The Old Man and the Sea" is...... & $\begin{array}{l}155 \\
155\end{array}$ & $\begin{array}{l}53.4 \% \\
53.4 \%\end{array}$ \\
\hline 3 & The greatest giant in China's modern literary world is...... & $\begin{array}{l}152 \\
152\end{array}$ & $\begin{array}{l}52.4 \% \\
52.4 \%\end{array}$ \\
\hline 4 & $\begin{array}{l}\text { The article known as " the historian's swan song, the rhythmless } \\
\text { "Lisao' " is..... }\end{array}$ & $\begin{array}{l}125 \\
125\end{array}$ & $\begin{array}{l}43.1 \% \\
43.1 \%\end{array}$ \\
\hline 5 & The author of Home is...... & $\begin{array}{l}129 \\
129\end{array}$ & $\begin{array}{l}44.4 \% \\
44.4 \%\end{array}$ \\
\hline $\begin{array}{l}6 \\
7\end{array}$ & $\begin{array}{l}\text { In the history of literature, the famous poets collectively known as " } \mathrm{Li} \\
\qquad \mathrm{Du} " \text { are..... }\end{array}$ & $\begin{array}{l}109 \\
109\end{array}$ & $\begin{array}{l}37.6 \% \\
37.6 \%\end{array}$ \\
\hline
\end{tabular}

2) Some university PE teachers have weak historical knowledge

TABLE II. CURRENT SITUATION OF HISTORICAL KNOWLEDGE MASTERING OF COLLEGE P.E. TEACHERS

\begin{tabular}{|c|c|c|c|}
\hline & Questions & $\begin{array}{c}\text { Number of } \\
\text { correct entries }\end{array}$ & Correct ratio \\
\hline 1 & Han, Tang, Song and Qing Dynasties can be sorted by time as...... & $\begin{array}{l}207 \\
207\end{array}$ & $\begin{array}{l}71.4 \% \\
71.4 \%\end{array}$ \\
\hline 2 & The Second World War Fascist Alliance was founded in...... (time) & $\begin{array}{l}83 \\
83\end{array}$ & $\begin{array}{l}28.6 \% \\
28.6 \%\end{array}$ \\
\hline 3 & The three major battles of the Liberation War were...... & $\begin{array}{l}257 \\
257\end{array}$ & $\begin{array}{l}88.6 \% \\
88.6 \%\end{array}$ \\
\hline 4 & The Nanjing Massacre took place in...... & $\begin{array}{l}148 \\
148\end{array}$ & $\begin{array}{l}51.0 \% \\
51.0 \%\end{array}$ \\
\hline
\end{tabular}

Some college PE teachers are not getting enoughknowledgeof history. History along with culture is the spiritual homeland of our nation. Learning historical knowledge will help to improve the cohesion, willpower, creativity and spiritual strength of our nation. The influence of thousands of years of Chinese history and culture has cultivated our fine moral character, noble sentiment, great demeanor, law - abiding, integrity and other qualities, which can help us to further improve our humanistic quality.
3) College P.E. teachers' artistic knowledge is relatively weak 
TABLE III. KNOWLEDGE OF FAMOUS PAINTERS

\begin{tabular}{|c|c|c|c|c|c|}
\hline & $\begin{array}{c}\text { Impression } \\
\text { Sunrise }\end{array}$ & $\begin{array}{c}\text { The Paint of } \\
\text { Galloping Horse }\end{array}$ & The Last Supper & Sunflowers & Shrimp \\
\hline $\begin{array}{c}\text { Number of } \\
\text { correct entries }\end{array}$ & 128 & 117 & 159 & 183 & 239 \\
\hline Rate & $44.1 \%$ & $778.3 \%$ & $54.8 \%$ & $63.1 \%$ & $82.4 \%$ \\
\hline
\end{tabular}

TABLE IV. INVESTIGATION OF MUSICAL INSTRUMENT PERFORMANCE

\begin{tabular}{|c|c|c|c|c|c|}
\hline & Flute & Erhu & Piano & Violin & Others \\
\hline $\begin{array}{c}\text { Number of } \\
\text { individuals }\end{array}$ & 55 & 23 & 26 & 9 & 0 \\
\hline Rate & $19.0 \%$ & $7.9 \%$ & $9.0 \%$ & $3.1 \%$ & $0 \%$ \\
\hline
\end{tabular}

The art knowledge that PE teachers in colleges and universities know is relatively weak. In particular, the survey of the performance of musical instruments shows that the ratio of PE teachers playing musical instruments is low. Around $8 \%$ of the interviewedcan play erhu, the rate of playing piano similar, butonly $3.1 \%$ of them can play violin. The aesthetic taste of PE teachers is supposed to be harmonious and elegant. Harmony, is to let students feel quiet and intoxicated; elegant and noble, to let students admire and yearn for. This aesthetic taste has become an atmosphere, a strength and a magnetic field, reflecting the physical education teacher's appearance, speech and behavior in the presentation of teaching contents, selection of teaching means and design of teaching procedures.

4) College P.E. teachers' philosophical and legal knowledge is not complete enough

TABLE V. CURRENT SITUATION OF PHYSICAL EDUCATION TEACHERS' KNOWLEDGE OF PHILOSOPHY AND LAW IN COLLEGES AND UNIVERSITIES

\begin{tabular}{|c|c|c|c|}
\hline & Questions & $\begin{array}{c}\text { Number of } \\
\text { correct entries }\end{array}$ & Correct ratio \\
\hline 1 & The most influential faction in ancient Chinese philosophy is...... & 242 & $83.4 \%$ \\
$83.4 \%$
\end{tabular}

According to the survey, $61.7 \%$ of the interviewedanswered the question of the famous German philosopher Hegel's core point of view correctly. The correct rate of answering the question " Teachers Law of the People's Republic of China" was $19.0 \%$, and the correct answer rate of the last but one was $33.1 \%$. The situation of the college PE teachers'mastery of philosophical and legal knowledge was negative.
B. Current Situation of Humanistic Spirit of Physical Education Teachers in Colleges and Universities

1) The ideals and beliefs of some college PE teachers are not strong enough 
TABLE VI.

IDEALS AND BELIEFS OF COLLEGE P.E. TEACHERS 1

\begin{tabular}{|c|c|c|c|c|}
\hline & Questions & Yes & It doesn't matter & No \\
\hline 1 & $\begin{array}{l}\text { There is a sense of sacredness and pride while } \\
\text { participating in the flag-raising ceremony }\end{array}$ & $83.4 \%$ & $16.6 \%$ & 0 \\
\hline 2 & $\begin{array}{c}\text { You care about the long-term prospects of this } \\
\text { major }\end{array}$ & $78.6 \%$ & $19.7 \%$ & $1.7 \%$ \\
\hline
\end{tabular}

This questionnaire shows that most PE teachers can study their subjects in depth and pay attention to the frontier development of the subject. The focus on " the long-term

prospects of this major" accounts for $78.6 \%$, which means there still being some teachersnot studying this professional knowledge well enough.

TABLE VII. IDEALS AND BELIEFS OF COLLEGE P.E. TEACHERS 2

\begin{tabular}{|c|c|c|c|c|c|}
\hline & Questions & Percentage of options $\%$ & $\begin{array}{l}\text { Percentage of } \\
\text { options } \%\end{array}$ & $\begin{array}{l}\text { Percentage of } \\
\text { options } \%\end{array}$ & $\begin{array}{l}\text { Percentage of } \\
\text { options } \%\end{array}$ \\
\hline 1 & $\begin{array}{l}\text { Your purpose of } \\
\text { learning }\end{array}$ & To seek utility 9.0 & $\begin{array}{c}\text { For practical use } \\
44.8\end{array}$ & $\begin{array}{c}\text { To earn money } \\
8.9\end{array}$ & $\begin{array}{c}\text { To achieve ideal } \\
37.1\end{array}$ \\
\hline 2 & $\begin{array}{c}\text { Your attitude toward } \\
\text { ugly acts }\end{array}$ & $\begin{array}{l}\text { Hate but unable to stop } \\
75.5 \\
\end{array}$ & $\begin{array}{c}\text { Don't want to stop } \\
7.2 \\
\end{array}$ & In cahoots 2.4 & Try to stop 14.9 \\
\hline 3 & Your main focus & Anti - corruption 62.0 & $\begin{array}{c}\text { Laid - off workers } \\
24.8\end{array}$ & $\begin{array}{c}\text { Party Congress } \\
12.1\end{array}$ & Tax evasion 1.1 \\
\hline 4 & $\begin{array}{l}\text { The event that arouse } \\
\text { your indignation most }\end{array}$ & National humiliation 45.9 & $\begin{array}{c}\text { Personal dignity } \\
30.0\end{array}$ & $\begin{array}{c}\text { Damage to } \\
\text { Environmental } \\
\text { Protection } 5.9\end{array}$ & Corruption 18.2 \\
\hline
\end{tabular}

Great eagerness in the pursuit of economic benefitscan be foundthrough this questionnaire. China's entry into the market economy-oriented stage showed an obvious utilitarian tendency in social life and work, focusing the learning interest and energy on more practical subjects while downplaying the learning accumulation of basic humanities. "Pursuingpragmatismand utility, ignoring cultivation" has become the value orientation of knowledge selection for a small number of PE teachers. They tend to pay too much attention to the cultivation of employability, but to neglect the construction of responsibility consciousness and the cultivation of emotional factors. Some PE teachers, whose ideals and beliefs are not firm enough,cannot link the development and future of the country with it of the individual, leading to the absence of humanistic spirit.

2) The moral qualities and standards of some college PE teachers need to be improved

TABLE VIII. PERSONALITY AND MORAL STATUS OF PHYSICAL EDUCATION TEACHERS IN COLLEGES AND UNIVERSITIES

\begin{tabular}{|c|c|c|c|c|}
\hline & Questions & Yes & $\begin{array}{l}\text { I can't tell for } \\
\text { sure }\end{array}$ & No \\
\hline 1 & Difficulties can be solved by collective cooperation & $\begin{array}{l}25.5 \% \\
25.5 \% \\
\end{array}$ & $\begin{array}{l}59.3 \% \\
59.3 \% \\
\end{array}$ & $\begin{array}{l}15.2 \% \\
15.2 \%\end{array}$ \\
\hline 2 & If personal interests were not satisfied, dedication is a lie & $\begin{array}{l}31.4 \% \\
31.4 \%\end{array}$ & $\begin{array}{l}36.9 \% \\
36.9 \%\end{array}$ & $\begin{array}{l}31.7 \% \\
31.7 \%\end{array}$ \\
\hline 3 & Do you comply with the Traffic Safety Law & $34.8 \%$ & $63.5 \%$ & $1.7 \%$ \\
\hline 4 & $\begin{array}{l}\text { Whether to pay attention to the cultivation of students' } \\
\text { humanistic quality }\end{array}$ & $38.6 \%$ & $60.4 \%$ & $1.0 \%$ \\
\hline 5 & In favor of helping the poor and the disabled & $83.5 \%$ & $15.5 \%$ & $1.0 \%$ \\
\hline 6 & $\begin{array}{l}\text { Physical education teachers in colleges and universities } \\
\text { are highly dedicated }\end{array}$ & $36.6 \%$ & $58.6 \%$ & $4.8 \%$ \\
\hline 7 & You emotionallyaccept banks saving taxes levied & $24.2 \%$ & $37.9 \%$ & $37.9 \%$ \\
\hline
\end{tabular}


The questionnaire shows that the situation of paying attention to the interdependent relationship between self and the development and survival of others is not perfect enough. The lack of humanistic spirit of some PE teachers in colleges and universities is mainly manifested in the distortion of life values, the monetization and extreme individualization of values, the obvious tendency of utilitarianism, and the emphasis on personal struggle and poor spirit of cooperation. The current education does not attach importance to the cultivation of humanistic spirit, which is the direct and main reason for its low level. Some PE teachers are unable to correctly understand and deal with the relationship between man and nature, between man and society, and between people. they cannot understand the lofty duties of teachers, either, thus failing to define the meaning and value of life.Another problem is that they may treat work perfunctorily, which affects the quality and effect of education. [6] It shows the tendency of utilitarian value orientation and the status quo that personality and moral standards need to be improved.

\section{CONCLUSIONS AND RECOMMENDATION}

\section{A. Carry out professional-curriculum-set reform}

The major courses of sports training, sports education and national traditional sports are mostly technical.The teaching targets are mostly determined at the technical level, with anemphasis put on results and sports achievements, while the content of humanistic knowledge is less considered in the curriculum design of talent training programs. In the face of the need to improve students' comprehensive quality education, it is particularly important to improve the humanistic quality of physical education teachers. We should reform the curriculum of talent training program to improve students' comprehensive quality education.

\section{B. Strengthen the perfecion of system}

Without a sound and perfect management system, it is also difficult to improve the humanistic quality of physical education teachers. To improve the humanistic quality of physical education teachers, both education and system are important parts. With the development of the reform of the personnel system in colleges and universities, teachers have implemented the system of post setting, appointment, promotion and performance evaluation. Through the reform of personnel system, the enthusiasm, the initiative and the creativity of teachers will be fully mobilized. Therefore, the establishment of a relatively perfect teacher management system is conducive to encourage teachers' professionalism and dedication, making this professional spirit last as well as forming a virtuous circle.

\section{Improve the reserve of humanistic knowledge and strengthen the transformation to humanistic spirit}

The improvement of physical education teachers humanistic quality is not only reflected in the accumulation of physical education teachers' humanistic knowledge, but also in the understanding ability of physical education teachers to humanistic knowledge and the degree of transformation to humanistic spirit, and is finally reflected in the shaping of physical education teachers' world outlook, philosophyon life and values. Physical education teachers only learn and accumulate humanistic knowledge without understanding and internalizing humanistic knowledge, so they are not able to form ideal humanistic spirits, to translate knowledge into their world outlook, philosophy on life and values, nor will they form their behaviors and ways with humanistic characteristics.

\section{Strengthen the construction of campus humanistic environment and create a good humanistic atmosphere}

Campus humanistic environment is a specific spiritual and cultural environment constructed by both teachers and students in colleges and universities. The environment created by cultural activities has an educational impact on people's psychology and regulates the behavior and thinking of all teachers and students at a higher level. A good campus humanistic environment can help college physical education teachers to cultivate and sublimate their moral character, emotion and will through subconscious psychological mechanism.

\section{E. Shape a good humanistic spirit}

The humanistic spirit of physical education teachers is reflected in all aspects and is the core content of humanistic quality. The main spirit of not serving foreign objects should be shaped and publicized to the majority of teachers. The dedication of teaching and educating people and loving their work and dedication; Persisting in truth and seeking truth from facts; The spirit of innovation aiming at the all-round development of people and society should strengthen the propaganda of noble humanistic spirit, form a good public opinion guidance among teachers, form a humanistic spirit atmosphere advocating career and be indifferent to fame and fortune [7]. Thereby to improve the humanistic quality of physical education teachersbetter.

\section{F. Strive to cultivate the personality charm of P.E. teachers}

The influence of a knowledgeable and experienced teacher on students stems from his personality charm. Personality charm is the embodiment of cultural accomplishment in physical education teachers' behavior and temperament. The personality charm of physical education teachers reflects social and cultural values, aesthetic feelings and so on, which can be an important reference for the construction of students' individual culture. Physical education teacher's personality charm can have a lasting impact on students directly. Physical education teacher's personality charm is manifested in body building, optimism and open - mindedness, tolerance and trust to students, so that students are willing to associate with them and regard physical education teachers as their role models. Therefore, cultivating physical education teachers' personality charm is conducive to improving the humanistic spirit of physical education teachers, thus forming radiation and improving the formation of humanistic quality of educational objects in the process of education. 


\section{REFERENCES}

[1] Chinese Dictionary [Z], Volume 8, Shanghai Chinese Dictionary Publishing House, 1991, 57. Malinowski, Cultural Theory [M], Huaxia Publishing House, 2002, 23.

[2] Hu Lizhang et al. What is humanistic quality education [J], Chinese higher education, 1996, 1.

[3] Wu Jian, the positive and negative impact of market economy on the reform and development of colleges and universities [J], Hong Kong and Macao Economy, January 2006, 32.

[4] Zhang Qizhi, University Teachers and Humanities [J], Educational Research in Tsinghua University, No. 4, 1999, $12 \sim 16$.

[5] Zhang Qizhi. Efforts should be made to improve the humanistic quality of university teachers [J]. China's Higher Education, 2000: 4.

[6] Zhu pengbing. current situation and countermeasures of university physical education teachers' humanistic quality [j]. journal of capital institute of physical education, December 2001: $51 \sim 53$.

[7] Xing Yongfu, Modern Educational Thought [M], Beijing Central Radio and Television University Press, 2001,125.

[8] Hongbin, Eight Ways to Strengthen Humanities Education in Colleges and Universities [J], Modern Education, June 2006, $64 \sim 66$. 